\title{
Approaches to Supporting Technical Education at Humanities-Oriented Schools
}

\author{
Milan KLEMENT \\ Palacký University Olomouc,Faculty of Education, Department of Technical Education \\ and Information Technology, Czech Republic \\ milan.klement@upol.cz
}

Abstract: Technological and polytechnic education in the field of computer aided design in 2D and 3D at non-technical secondary schools represents a new and relatively unexplored area.

Approaches to promoting technological and polytechnic education are numerous. However, the problem tends to be simplified to the issue of processing materials, which does not take into account the wide range of techniques and technologies, nowadays largely represented by information and communication technologies.

With these facts in mind, an experiment was conducted, focused on the addition of a thematic unit of computer aided design in 2D and 3D supported by CAD system to the curriculum of grammar schools, for the time period of 6 months. The submitted study presents a summary of contributions and results of the experiment, using the method of investigative research carried out among the students and teachers of grammar schools, who had implemented the training of the above mentioned subject.

Keywords: Polytechnic; education; experiment; Computer-Aided Design (CAD);Autodesk AutoCad 2015

\section{INTRODUCTION}

Technology is an internal part of our life, it is all around us. Nowadays, a person without necessary basic technical knowledge and skills would not be able to perform their social function properly, and, consequently, would not live a full life (Lee, Rojewski \& Gregg, 2016). Therefore, elementary technical knowledge and skills should be mediated to the general public, not just to the students of technical secondary schools, by the educational system. In terms of advanced educational systems, elementary technology training represents an integral part of the general curriculum taught at elementary and secondary schools(Silva, Pelissari \& Steimbach, 2013). It is transferred to pupils and students via a school subject, different not only in name (practical training, practical activities, technical training, technical practice, technique, practice, technology etc.), but also in scope and content.

Over the recent years, the term "subjects of technical character" has been used in professional literature (Idrus, Mond \& Abdullah, 2010). By means of this subject, pupils acquire not only theoretical knowledge, but also elementary work skills. The emphasis is usually placed on technical creativity, depending on students' fields of interest, and the training is carried out mostly within the framework ofoptional subjects (Leung \& Wang, 2015). Despite the rapid development of computer technology in all developed countries`education systems, elementary manual activities of technical nature such as woodworking, metalworking, working with tools and simple machines, electrical work etc.), remain a part of the curriculum. A combination of the two aforementioned is more and more common. The aim of the technology or polytechnic education is to develop the skills of the learners in manipulating working tools and machines, adopting work culture, and to acquaint them with the scientific principles of contemporary production, safety rules, etc. (Reis \& Garcia, 2016). 
At present, these objectives are further developed by the supportive role of ICT, as information technology today covers or supports a significant part of industrial production. The aforementioned goals shall be well achieved in technically oriented subjects, which are based on the combination of the two stated goal segments, and the content and process side of which are close to a number of professions, not only these called technical today (Manullang \& Kons, 2012).

Even though teaching at primary and secondary schools is primarily focused on general training, preparation for the use of computer technology and technology in general grows in importance as a component of education (Granath, 2003, p. 129). These efforts have not only been declared, but also embedded in a wide range of curricular and policy documents, and in many cases they have also been financially supported by various grants. The above stated facts indicate that education systems clearly aim to promote polytechnic education. Unfortunately, at least in terms of the Czech education system, it is not always the case. During 2006 and 2007, the Faculty of Informatics and Statistics of the University of Economics in Prague in cooperation with the company CACIO-CSSI-SPIS conducted a complex research to analyze students' of grammar schools readiness for academic studies at technical universities.

The study involved 53 faculties all over the country. The conclusions of the study were alarming, as they revealed a lack of experts in technical fields, as well as the absence of expertise among teaching staff, and an inadequate level of education at grammar schools in technical disciplines, based on the rudiments of drawing documentation, as one of the most important prerequisites for successful studies at technical universities. Moreover, according to the conducted study, only a small percentage of grammar schools`students proceed with their studies at technical universities. They prefer fields of study more related to humanities, though their dispositions to study at technical universities might be very good (mathematics, chemistry, physics, etc.). Following the results of the aforementioned study, the author of this paper conducted a similar research in 2015 (Klement \& Kubricky, 2014), a part of which was carried out at six 8 and 6 year grammar schools. Among others, a question concerning the reason why so few students of these grammar schools apply for technically oriented universities was asked. The most frequent answer received from the students was a claim that they were unable to assess the benefits of technology studies, because their high school's curriculum did not involve any subject which would at least partially expound technology and technical issues to them.

Based on these results, we started to prepare in 2015 and implemented in 2016 an experiment (Ferreira, Caires \& Pitarma, 2015), based on the inclusion to the set of ICT subjects taught at 8 and 6 year grammar schools of a thematic unit "Application of mathematics and chemistry in computer-aided technical drawing", which integrated both the technical area of technical drawing and drawing documentation, and the area of specialized CAD (Computer-Aided Design) software tools used in these activities (Klement, 2003). The experiment thus consisted in the introduction of a new thematic unit to the established curriculum, and in the evaluation of the impact of thus conceived education on the students.

Mathematics as a subject was not chosen randomly. It is one of the less popular school subjects (Federich \& Munich, 2015), and at the same time one of those which we don t have a facility for, as show international comparisons. On the other hand, the Czech state sees knowledge of mathematics in pupils and students as crucial, which is reflected in the fact that this year is historically the first one when elementary school leavers (15 year olds) who want to pursue their studies at high schools have to pass unified tests in the Czechlanguage, as well as Math. Moreover, once they are accepted, they will have to face the fact that they will be the first graduates who will obligatorily take their school leaving exam in Math, which until now has been voluntary (in favor of foreign languages). General feeling about this change in the school system is despair, not only of the children, but also their parents. 
According to most Czech education experts, such feelings stem from the only slowly improving quality of teaching Math at Czech schools, and from the newly introduced obligations, regarded rather as restrictions. The resistance to Mathematics is often encouraged in children by asking for knowledge at an extent they do not understand. At the same time, young children often approach Math playfully and with enthusiasm which is, however, fading away, as more and more memorizing and complex theories are required. Therefore, CAD, the method chosen by us, may be exactly the element that would give back to the teaching of Mathematics playability and visibility,as opposed to memorization and theory.

As far as chemistry is concerned, it is more or less peripheral in terms of the direction of further studies of Czech pupils and students. It shows, for example, in the number of students who apply for specialized chemistry-related fields at Czech Faculties of Science, as opposed to the number of applicants interested in humanities, which is many times higher.

\section{SPATIAL IMAGINATION AND ITS DEVELOPMENT}

Despite the fact that most of us do not even realize it, spatial imagination accompanies us throughout our lives and at every step. Spatial orientation begins to develop as early as in infancy, when the child learns to follow the trajectory of moving objects and focus on the immediate area (Markson \& Paterson, 2009). The development starts in the vertical direction when a child, thanks to the Earth`s gravity, adopts the notions of up and down. Anteroposterior and horizontal movements follow, improving and deepening of the perception then go on throughout the rest of our lives. We cannot classify imagination as a purely mathematical, or psychological ability, however, there are fields of human activity which require a developed spatial imagination, for example sculpture, topology, architecture, building construction, and other technical disciplines.

According to Jirotkova (1990), spatial imagination equals intellectual ability to purposefully recall:

- earlier seen or perceived objects in three-dimensional space and recall their properties, location, and spatial relationships,

- sooner or at any given moment seen or perceived objects in a different relative position than they were at, or are actually perceived,

- object in space based on its planar visualization,

- non-existent real object in three dimensional space on the basis of its verbal description.

Spatial imagination develops along with the development of certain skills, such as the ability to:

- communicate (especially graphic communication),

- use tools and features,

- work with mathematical and technical terms,

- apply mathematical and technical knowledge,

- explore and work creatively.

Spatial imagination can serve various purposes. It can be a useful tool, an auxiliary way of thinking, a method to obtain information or to formulate a task, and/or a means to solve a particular problem. Thanks to the versatility and the use of spatial imagination, there are many different definitions of the collocation. Obviously, the definition by a psychologist will differ from the one by a neurologist, a teacher, or an engineer. Apparently the broadest definition of the term has been provided by a pedagogical sciences professor H. Gardner (1999): "The core of spatial imagination are the capabilities which ensure an accurate perception of the visual world, facilitate the transformation and modification of the original perceptions, and create a visual experience from one's own mental images, even in the absence of outward stimuli effect." 
The aforementioned functions of spatial imagination are used in mathematics in order to solve various tasks, in chemistry for visualizing chemical bonds, in technical drawing, and while designing solids, shapes, and objects. That is why lessons of technical drawing or computer-aided technical drawing create favorable conditions for the development of spatial imagination and technical thinking (Kropáč, 2004). To be able to compile, and to project appropriate teaching of 2D and 3D drawing documentation based on the use of up-to-date electronic study materials, it is necessary to continuously determine their impact on the target group, and regularly identify the views and the attitudes of the later. Based on the conducted investigation, it is possible to correct some of the negative side effects or, on the other hand, accentuate the positive effects. Teaching computer-aided technical drawing, supported by well selected teaching materials thus offers many a possibility for more effective teaching and developing interdisciplinary links (Bracey, 1994).

\section{SETTING CONDITIONS FOR THE IMPLEMENTATION OF THE EXPERIMENT}

A necessary precondition for the implementation of the experiment was to create its own concept and content of education, focused on the use of CAD systems, for the purpose of the enrichment of teaching of mathematics and chemistry at 8 or 6 year grammar schools with the practical application based on the use of computer-aided technical drawing. A new training module "Application of mathematics and chemistry in technical drawing" was developed, the aim of which was to elaborate interdisciplinary links, interconnect theory and practice via real life examples and practical tasks (Bracey, 1994), and last but not least contribute to a substantial development of the competencies of the students in the field of computer-aided technical drawing (Klement, 2003), as one of the important factors facilitating their potential further studies at technically oriented universities.

The aforementioned module enabled a substantial development of interdisciplinary links between math and chemistry, as a consequence of practical use of the students' knowledge of the two subjects during the visualization of objects in 2D and 3D space, elaborated to technical drawing, as one of the basic means of graphic communication. The practical application related mainly to the following fields:

- Plane geometry (parallels, skew lines, etc.).

- Spatial geometry (spatial solids and surfaces, conics, etc.).

- Boolean algebra (operators and, or, or and their graphic visualization).

- Descriptive geometry (traces of planes, intersections between planes, solid edges).

- Visualization of the atomic structure of matter (visualization of the core structure and valence spheres).

- Modelling of element molecules (visualization of molecular structures).

- Modelling of compound molecules (visualization of the molecular bonds).

To be able to implement the aforementioned experiment, a joint project of the Department of Technical Education and Information Technology of the Faculty of Education of Palacký University Olomouc and 6 partner 8 and 6 year grammar schools from Olomouc region called CAD - computer-aided technical drawing at schools, was carried out. The project was aimed at an extension of the subject matter of math and chemistry lessons by practical application of computer-aided technical drawing in the second or third year of a four-year program of study 79-41-K/41, or equivalent years in a six-year program of study 79-41-K/61, and/or eight-year program of study 79-41-K/81 of grammar schools. It was based on an active approach of teachers (methodologists) to the development and implementation of a new learning content and application of subjects, creation of a new learning program, including its verification in live instruction. Moreover, the individual key activities comprised all the basic processes associated with the change in the content of particular subjects` curricula, focused on practical application and use of computer-aided technical drawing in lessons of mathematics and chemistry. 
Due to the activity character of the realized teaching, which took account of the needs of 6 and 8 year grammar schools, a practical application of knowledge on concrete examples was used as a method, including the creation of 2D and 3D visualizations which enabled the students to better understand the subject matter (Klement \& Kubrický, 2014). Thus conceived concept guaranteed that the students would be able to practically apply their knowledge to real-world examples. It should be noted that the structure of the particular units was mostly focused on mastering the knowledge and the skills immediately required for basic orientation in the field of creating 2D and 3D drawing documentation in AutoCAD $2015^{1}$ system (Klement \& Kubricky, 2014). For the contents of particular training modules see below:

Table1. The contents of the thematic unit

\begin{tabular}{|c|c|}
\hline Name of the training module & Content of the training module \\
\hline $\begin{array}{l}\text { Training module 01: Applica- } \\
\text { tions of mathematics: Introduc- } \\
\text { tion to plane geometry }\end{array}$ & $\begin{array}{l}\text { The module familiarizes students with the basics of the operation and the } \\
\text { use of the AutoCAD } 2015 \text { user interface. Via practical examples, students } \\
\text { are gradually informed about various parts of the interface and functions } \\
\text { of AutoCAD 2015, and alsoget acquainted with the creationof basic } \\
\text { planegeometric figures. }\end{array}$ \\
\hline $\begin{array}{l}\text { Training module } 02: \text { Applica- } \\
\text { tions of mathematics: Creation } \\
\text { and basic alteration of geomet- } \\
\text { ric figures }\end{array}$ & $\begin{array}{l}\text { The module familiarizes students with further possibilitiesof the } \\
\text { operation and theuse of the AutoCAD } 2015 \text { userinterface. Via practical } \\
\text { examples, students are gradually informed aboutfurther parts and } \\
\text { functionsof AutoCAD } 2015 \text { interface, andalsoget acquainted with the } \\
\text { creationof further planegeometric figures. }\end{array}$ \\
\hline $\begin{array}{l}\text { Training module 03: Applica- } \\
\text { tions of mathematics: Creation } \\
\text { and more advanced alteration } \\
\text { of geometric figures }\end{array}$ & $\begin{array}{l}\text { The module builds on knowledge gainedin previous teaching modules } 01 \\
\text { and } 02 \text { and extends themby introducing possible alterations of } \\
\text { planegeometric figures. Students are gradually initiated to the practical } \\
\text { application ofthese modification options, both via frontal teaching and } \\
\text { practical examples requiring individual work. }\end{array}$ \\
\hline $\begin{array}{l}\text { Training module 04: Applica- } \\
\text { tions of mathematics: Creation } \\
\text { and advanced alteration of } \\
\text { plane figures }\end{array}$ & $\begin{array}{l}\text { The module builds on knowledge gainedin previous learning modules } 01 \text {, } \\
02 \text { and } 03 \text {, and extends them by introducing possible alterations of } \\
\text { planegeometric figures. Students are gradually initiated to the practical } \\
\text { application ofthese modification options, both via frontal teaching and } \\
\text { practical examples requiring individual work. }\end{array}$ \\
\hline $\begin{array}{l}\text { Training module 05: Denoting } \\
\text { dimensions of plane figures }\end{array}$ & $\begin{array}{l}\text { The module is focused on denoting the dimensions of plane figures. } \\
\text { Students are gradually acquainted with the basic principles and } \\
\text { approaches regarding dimensioning of plane figures. They apply this } \\
\text { knowledge in practice by creating both diameter and radius dimensions. }\end{array}$ \\
\hline $\begin{array}{l}\text { Training module } 06: \\
\text { Applications of mathematics: } \\
\text { Filling in plane figures }\end{array}$ & $\begin{array}{l}\text { The module is focused on filling in, or hatching, plane geometric figures. } \\
\text { Students are gradually acquainted with the basic principles of and } \\
\text { approaches to hatching plane figures. They apply the knowledge in } \\
\text { practice by creating hatched areas, both by selecting interiorpoints and } \\
\text { border areas. }\end{array}$ \\
\hline
\end{tabular}

${ }^{1}$ AutoCAD is a commercial computer-aided design (CAD) and drafting software application. Developed and marketed by Autodesk. AutoCAD was first released in December 1982 as a desktop app running on microcomputers with internal graphics controllers. Prior to the introduction of AutoCAD, most commercial CAD programs ran on mainframe computers or minicomputers, with each CAD operator (user) working at a separate graphics terminal. Since 2015, AutoCAD was released as a mobile- and web app as well, marketed as AutoCAD 360. 


\begin{tabular}{|l|l|}
\hline $\begin{array}{l}\text { Training module 07: Applica- } \\
\text { tions of mathematics: Basics of } \\
\text { spatial geometry }\end{array}$ & $\begin{array}{l}\text { Training module 07 is intended to introduce students to the basics ofs } \\
\text { patial geometry and spatial modeling in the AutoCAD 2015 system. By } \\
\text { means of both frontal teaching and individual work, basic spatial elements } \\
\text { and some selected surfaces are created by the students. They thus apply } \\
\text { the knowledge of mathematics, which they extend with practical activities } \\
\text { focused onthe modeling of 3Dscenes andfigures. }\end{array}$ \\
\hline $\begin{array}{l}\text { Training module 08: } \\
\text { Applications of mathematics: } \\
\text { Visualization of compounds and }\end{array}$ & $\begin{array}{l}\text { The module follows up with the training module 07 and extends it } \\
\text { toward practical applications of the knowledge of chemistry, especially } \\
\text { the knowledge focused on the visualization of chemical elements and } \\
\text { compounds. Students individually create 3D models of elements`and } \\
\text { compounds`atoms and molecules in 3D space, using the AutoCAD 2015 } \\
\text { system. }\end{array}$ \\
\hline $\begin{array}{l}\text { Training module 09: Applica- } \\
\text { tions of mathematics: Boolean } \\
\text { operations in space }\end{array}$ & $\begin{array}{l}\text { The module is focused on the practical application of Boolean operations } \\
\text { on solids and surfaces in 3D space. On practical examples, students will be } \\
\text { acquainted with the union, difference, and intersection operations. They } \\
\text { will thus follow up with the subject matter of mathematics lessons, more } \\
\text { specifically to Boolean algebra, which shall be practically applied in the } \\
\text { system of AutoCAD 2015. }\end{array}$ \\
\hline $\begin{array}{l}\text { Training module 10: Applica- } \\
\text { tions of mathematics: Rotation } \\
\text { and projection in space }\end{array}$ & $\begin{array}{l}\text { The module focuses on the practical application of operations focused on } \\
\text { the creation of spatial objects and surfaces in 3D space. Students shall } \\
\text { beacquainted with the use of rotation and projection in practice. They will } \\
\text { thus follow up with the subject matter taught in mathematics lessons, } \\
\text { more specifically with the issue of transformation in 3D space, which they } \\
\text { shall apply in practice in the AutoCAD 2015 system. }\end{array}$ \\
\hline
\end{tabular}

Overall, the thematic unit "Application of mathematics and chemistry in computer-aided technical drawing" was divided into 10 separate training modules, following each other. The time allocation of individual training modules was two lessons. The training modules were introduced into the curriculum and taught in the year 2016 at six 8 or 6 year grammar schools, they were attended by a total of 301 students, and 12 teachers were involved. Upon completion of this conceived training, it was possible to evaluate the impact and the results of the experimental subject matter from the perspective of students and teachers. The following text describes the procedure and the method of the evaluation of the results and of the impact from the students` and teachers' point of view.

DESCRIPTION OF THE CONDITIONS, THE SAMPLE, AND THE METHOD OF EVALUATING THE

\section{RESULTS OF THE EXPERIMENT}

The actual teaching of the thematic unit "Application of mathematics and chemistry in computer-aided computer drawing" was followed by a research investigation conducted at all involved schools. The investigation was aimed at a determination of opinions and attitudes of the stated schools` students on the instruction realized, and on its real impact on the educational process at these schools. A total of 301 students of the students who had experienced the lessons enriched by the experimental learning content participated in the research. Moreover, 12 teachers were involved. They contributed to the preparation of the experimental educational content, and attended a course aimed at the use of the CAD system in education.

As the principal tool for obtaining the data necessary for the implementation of the research investigation, a questionnaire was used. Within the framework of research methods classification structure, questionnaire 
Approaches to Supporting Technical Education at Humanities-Oriented Schools

belongs to indirect methods of investigation. According to N. Ničkovič, a questionnaire can be characterized as "a specific measuring device by means of which opinions of individuals on particular phenomena are explored" (Babbie, 2014). From the point of view of the person or respondent questioned, these phenomena can refer either to external phenomena, or to internal processes. That is why a structured evaluation questionnaire meeting the requirements of the research investigation was created. It stemmed from personal experience and enabled us to find about the students' and teachers'views on and attitudes to the teaching of the thematic unit "Application of mathematics and chemistry in computer aided technical drawing".

Students and teachers were asked to fill out the questionnaire anonymously and thus present their views on and attitudes to particular questionnaire questions. They were asked to express their opinion by ticking the YES or NO option in compliance with their personal preference. For the description of the research sample, see Table number 2 and 3 below.

Table2. Structure of the research sample - students

\begin{tabular}{|l|l|l|}
\hline Gender & Number of respondents & Number of respondents in \% \\
\hline Boys & 122 & $40.5 \%$ \\
\hline Girls & 179 & $59.5 \%$ \\
\hline Total & 301 & $100 \%$ \\
\hline
\end{tabular}

Table3. Structure of the research sample - teachers

\begin{tabular}{|l|l|l|}
\hline Gender & $\begin{array}{l}\text { Number of filled-in self-evaluation } \\
\text { questionnaires * }\end{array}$ & $\begin{array}{l}\text { Number of filled-in self-evaluation } \\
\text { questionnaires in \% }\end{array}$ \\
\hline Men & 10 & $52.63 \%$ \\
\hline Women & 9 & $47.37 \%$ \\
\hline Total & 19 & $100 \%$ \\
\hline
\end{tabular}

* The number of filled-in self-evaluation questionnaires corresponds with the fact that every teacher involved in the project carried out individual evaluation once or twice, that is to say, for the first time after having taught 5 training modules and for the second time, after having taught all 10 training modules. This measure led to a significant objectivisation in the evaluation of the contribution of AutoCAD 2015applicatons' teaching.

Teachers therefore had the opportunity to fill in at least one self-evaluation questionnaire, and enter into it the outcomes of their observation as well as the results of the teaching of the thematical unit focused on applying the math and chemistry knowledge, acquired by means of computer-aided drawing in AutoCAD 2015 environment, at their schools. The first wave of observations took place between February and April 2016 (evaluation of the first 5 training modules), subsequently, the second wave was carried out between April and July 2016 (self-evaluation of all 10 learning modules). Overall, a total of 190 taught training modules of the thematical unit "Application of maths and chemistry knowledge acquired by means of computer-aided drawing in AutoCAD 2015 environment system," were evaluated. The evaluation was carried out in real terms of the educational process conducted at six 8-year grammar schools and therefore the results can be further classified as conclusive.

As the main method for the evaluation of the acquired research data we used the chi-square test (Babbie, 2014), which enabled a determination of the dependency of the research outcomes on a significant sign of a group of respondents, that is to say on gender. In order to determine the potency of the particular groups of respondents, whose answers were the same, basic descriptive statistics and their visualization via tables were used. For the purpose of calculating, the statistical system Statistica 11 (Klimek, Stříž\&asal, 2009) was applied. The following text presents some of the partial results of the realized survey, the aim of which was to find about the opinions and attitudes of students and teachers of 6 and 8 year grammar schools on and to the teaching of the topic "Application of mathematics and chemistry in computer- aided technical drawing" and its real impact on the educational process at these schools. 
Approaches to Supporting Technical Education at Humanities-Oriented Schools

PARTIAL OUTCOMES OF THE CONDUCTED RESEARCH INVESTIGATION FOCUSED ON STUDENTS

In further text, we are presenting the outcomes of the conducted research, organized in six separate areas. Each analysis included the calculation of the pivot table, the calculation of the percentage, and the estimation of the particular outcomes' dependency on the sex of respondents. For the purpose of simplicity and clarity, all three analyzes are comprised in one table.

The first area examined was the level of interest in AutoCAD applications shown by the students. By answering the relevant question, students expressed their opinion on whether teaching supported by AutoCAD 2015 application was interesting for them and whether producing 2D and 3D drawing documentation was to any benefit. A summary of the outcomes based on their responses is illustrated by the Table 4 below.

Table4. Interest in computer-aided computer drawing teaching

\begin{tabular}{|c|c|c|c|}
\hline \multicolumn{4}{|c|}{ Contingency table for: $\mathrm{n}=301$} \\
\hline \multicolumn{4}{|c|}{ Pearson`s chi square: $p=0,048454$} \\
\hline \multicolumn{4}{|c|}{ Was computer aided technical drawing interesting for you? } \\
\hline Gender of respondents & Boys & Girls & Row totals \\
\hline No, it was not - frequency & 25 & 55 & $80(27 \%)$ \\
\hline Yes, it was - frequency & 97 & 124 & $221(73 \%)$ \\
\hline All groups - frequency & 122 & 179 & $301(100 \%)$ \\
\hline
\end{tabular}

According to the findings presented in Table 4, it is possible to state that teaching of AutoCAD 2015 applications caught the interest of almost three quarters of students (73\%) of 6 and 8 year grammar schools. The initial presumption that the inclusion of this experimental educational content would be regarded as interesting and beneficial by the students was hereby confirmed.

Furthermore, it is possible to conclude that there is a statistically significant difference $(p=0.048454)$ between the frequency of responses given by girls and boys. The boys interest in AutoCAD applications 2015 proved significantly stronger than that of the girls, which, given the fact that technically oriented activities have always been more popular with boys, is not a surprising result and does not defy the average.

Next area of research was focused on whether the students consider teaching of AutoCAD 2015 applications as difficult, or more difficult than other activities aimed at the use of ICT. By answering the relevant questions, students expressed their opinion on whether the learning content of this thematic unit was more difficult for them to understand than the learning content of the other subjects focused on ICT, mathematics and/or chemistry. A summary of the outcomes based on their responses is illustrated by the Table 5 below.

Table5. The level of difficulty of teaching AutoCAD 2015 applications

Contingency table for: $\mathrm{n}=301$

Pearson`s chi square: $\mathrm{p}=0,070579$

Did you find the lessons of computer-aided drawing difficult?

\begin{tabular}{|l|l|l|l|}
\hline Gender of respondents & Boys & Girls & Row totals \\
\hline No, I did not- frequency & 96 & 124 & $220(73 \%)$ \\
\hline Yes, I did - frequency & 26 & 55 & $81(27 \%)$ \\
\hline All groups - frequency & 122 & 179 & $301(100 \%)$ \\
\hline
\end{tabular}

American Research Journal of Humanities and Social Sciences

Page 8 
Based on the findings presented in Table 5, it is more than obvious that the vast majority of students of 6 and 8 year grammar schools do not consider teaching of AutoCAD 2015 applications as difficult, ormore difficult than other thematic units focused on ICT, mathematics, and/or chemistry. This result indicates and confirms, among other things, that the general popularity of the subjects focused on sciences is low and that students therefore welcome every opportunity to enrich the lessons.

Furthermore, it is possible to conclude that there is a statistically significant difference $(p=0.070579)$ between the frequency of responses given by girls and boys. This time it was the girls who, in comparison to boys, showed a statistically significant enthusiasm for the inclusion of the experimental learning content into teaching, because they regarded it as less difficult.

The third area investigated was focused on the question whether the students would welcome the opportunity to further educate themselves in the field of 2D and 3D drawing documentation using AutoCAD system in 2015, both controlled and independent. By answering the relevant questions, students expressed their opinion on whether they found these issues as engaging and evolving as to be dealt with further on in the future. A summary of the outcomes based on their responses is illustrated by the Table 6 below.

Table6. Level of interest in further education in creating drawing documentation supported by the use of AutoCAD system

Contingency table for: $\mathrm{n}=301$

Pearson`s chi square: $\mathrm{p}=0,002095$

Would you like to educate yourself further in the field of computer-aided drawing?

\begin{tabular}{|l|l|l|l|}
\hline Gender of respondents & Boys & Girls & Row totals \\
\hline No, I would not - frequency & 70 & 133 & $203(67 \%)$ \\
\hline Yes, I would - frequency & 52 & 46 & $98(33 \%)$ \\
\hline All groups - frequency & 122 & 179 & $301(100 \%)$ \\
\hline
\end{tabular}

According to the findings presented in Table 6, it is more than obvious that only less than one third of the students, more specifically 33\%, would like to be further educated in the field of the creation of 2D and 3D drawings using AutoCAD 2015 system. Although this result is inconsistent with the first stated analysis relating to the interest in this teaching, it can be explained by the fact that the general level of intentionality in education is currently lower and further education is thus refused by the students.

Furthermore, it is possible to conclude that there is a statistically significant difference $(p=0.002095)$ between the frequency of responses given by girls and boys, as the girls rejected further education in the field of AutoCAD 2015 applications more often than boys. Even this result is by no means unusual, and can be attributed to the generally lower popularity of technically and biologically oriented subjects among girls.

Yet another area of research was focused on the question whether the students actually apply the knowledge and skills gained in AutoCAD lessons in further education. The assumption was that especially those students who would consider further education in technical fields might show a preference for this need. On the basis of this analysis we can suppose those students might be interested in further technical education. A summary of the outcomes based on their responses is illustrated by the Table 7 below. 
Approaches to Supporting Technical Education at Humanities-Oriented Schools

Table7. The use of the outputs of AutoCAD 2015 applications teaching in further education

\begin{tabular}{|c|c|c|c|}
\hline $\begin{array}{l}\text { Contingency table for: } \mathrm{n}= \\
\text { Pearson`s chi square: } \mathrm{p}=\mathrm{c} \\
\text { Do you think you will use }\end{array}$ & ided d & ducati & \\
\hline Gender of respondents & Boys & Girls & Row totals \\
\hline No, I will not - frequency & 68 & 130 & $198(66 \%)$ \\
\hline Yes, I will - frequency & 54 & 49 & $103(34 \%)$ \\
\hline All groups - frequency & 122 & 179 & $301(100 \%)$ \\
\hline
\end{tabular}

Based on the findings presented in Table 7, it is obvious that the vast majority of students do understand the necessity of teaching AutoCAD 2015 applications for creating 2D and 3D drawing documentation, because 34\% of them claimed that the subject matter would be necessary for their further education. It is therefore possible to deduce that the level of interest in technical fields, where the use of CAD systems is more than common, is relatively high.

Furthermore, it is possible to conclude that there is a statistically significant difference $(p=0.002431)$ between the frequency of responses given by girls and boys, as the boys perceived the use of CAD systems for further education as more important than girls, which again is a result that could have been be expected.

The fifth area of research was focused on the question whether the students actually apply the knowledge and skills gained in lessons focused on the creation of 2D and 3D drawing documentation in everyday life. Once again, the question is related, though indirectly, to the prospective professional orientation of the students and to their interest in the further career in technical fields. A summary of the outcomes based on their responses is illustrated by the Table 8 below.

Table8. Benefit of the AutoCAD 2015 applications teaching from future perspective

Contingency table for: $\mathrm{n}=301$

Pearson`s chi square: $p=0,000381$

Do you consider computer-aided drawing beneficial from future perspective?

\begin{tabular}{|l|l|l|l|}
\hline Gender of respondents & Boys & Girls & Row totals \\
\hline No, I do not - frequency & 56 & 119 & $175(58 \%)$ \\
\hline Yes, I do - frequency & 66 & 60 & $126(42 \%)$ \\
\hline All groups - frequency & 122 & 179 & $301(100 \%)$ \\
\hline
\end{tabular}

Based on the findings presented in Table 8, it is obvious that the students understand the need for teaching applications AutoCAD 2015 combined with the creation of 2D and 3D technical drawings, because 42\% of them expressed a positive belief concerning the future use of the outputs of this instruction.

Although there is a statistically significant difference $(p=0.000381)$ between the frequency of responses given by boys and girls, in general both girls and boys consider the AutoCAD 2015 application of low benefit for their future lives.

The last area of investigation was focused on the question whether the students perceive a change towards better understanding of the principles and functioning of computer equipment and software tools thanks to the lessons of the creation of 2D and 3D technical drawings in AutoCAD 2015, in other words, whether the students understood better other subject matters related to ICT. A summary of the outcomes based on their responses is illustrated by the Table 9 below. 
Approaches to Supporting Technical Education at Humanities-Oriented Schools

Table9. Better understanding of the principles and the operation of computer technology

Contingency table for: $\mathrm{n}=301$

Pearson`s chi square: $\mathrm{p}=0,245060$

Do you think that you understand the operation of computer technology better now?

\begin{tabular}{|l|l|l|l|}
\hline Gender of respondents & Boys & Girls & Row totals \\
\hline No, I do not - frequency & 51 & 87 & $138(46 \%)$ \\
\hline Yes, I do - frequency & 71 & 92 & $163(54 \%)$ \\
\hline All groups - frequency & 122 & 179 & $301(100 \%)$ \\
\hline
\end{tabular}

Based on the findings presented in Table 9, it is more than obvious that the students now understand the functioning of computer technology better than it was before the implementation of the teaching of AutoCAD 2015 applications. Experimental learning content thus developed the students' knowledge and skills in the field of the creation of 2D and 3D drawings, and related interdisciplinary links between mathematics and chemistry. Moreover, it contributed to a deeper understanding of the principles and operation of ICT, and its possible use.

Furthermore, it is possible to conclude that there was no statistically significant difference $(p=0.245060)$ between the frequency of responses given by girls and boys, and therefore these two groups share the same opinion.

\section{PARTIAL OUTCOMES OF THE CONDUCTED RESEARCH INVESTIGATION FOCUSED ON TEACHERS}

The firstareaexaminedwas the level of interest in 2D and 3D drawing documentation in the AutoCAD environment shown by the students. It was determined via direct monitoring of the training, carried out by the teachers during the lessons. It is necessary to mention here that the outcomes based on students`own declarations correspond with the outcomes stated hereinafter. However, students claimed a somewhat lower level of interest.A summary ofthe outcomes based on the teachers` responsesis illustratedby the Table 10 below.

Table10. The level of students` interest in teaching AutoCAD 2015 applications.

Contingency table for: $\mathrm{n}=19$

Pearson`s chi square: $\mathrm{p}=0.278821$

Did computer aided technical drawing catch the students ' interest?

\begin{tabular}{|l|l|l|l|}
\hline Gender of respondents & Men & Women & Row totals \\
\hline No, it did not - frequency & 0 & 1 & $1(5 \%)$ \\
\hline Yes, it did - frequency & 10 & 8 & $18(95 \%)$ \\
\hline All groups - frequency & 10 & 9 & $19(100 \%)$ \\
\hline
\end{tabular}

From the results shown in Table 10, it isquiteclear thatthe vast majorityof teachersindicated thatteachingAutoCAD 2015had caught the students` interest. Furthermore, it ispossible to say thatthere is nostatistically significant difference $(p=0.278821)$ between the frequency of responses given by men and women. In other words, men and women both claimed that the teaching had been interesting for the students.

Another questione xamined was whether the inclusion to the teaching of the thematic unit "Application of mathematicsand chemistry knowledge acquired by means of computer-aided drawing in AutoCAD 2015 environment system," had led to increasing students 'motivation, from the perspective of the teachers. As motivationis one ofthe most important psychological preconditions for successful and effective teaching, it has a major impact on the outcomes of the latter. A summary of the outcomes based on the teachers' answers is given in the below Table number 11. 
Approaches to Supporting Technical Education at Humanities-Oriented Schools

Table11. The level of students' motivation in the course of teachingAutoCAD 2015 applications

Contingency table for: $\mathrm{n}=19$

Pearson`s chi square: $\mathrm{p}=0,465695$

Did the students` motivation level increase in the course of training?

\begin{tabular}{|l|l|l|l|}
\hline Gender of respondents & Men & Women & Row totals \\
\hline No, it did not - frequency & 1 & 2 & $3(16 \%)$ \\
\hline Yes, it did - frequency & 9 & 7 & $16(84 \%)$ \\
\hline All groups - frequency & 10 & 9 & $19(100 \%)$ \\
\hline
\end{tabular}

From the results shown in Table 11 it is clear that the majorityof the teacherscame to the conclusionthat the inclusion AutoCAD 2015 to the teaching had significantlyincreased themotivationof studentsto study. Teaching creationof 2D and 3Ddrawing documentationin AutoCAD 2015 systemthereforecan be described asa veryusefultool forincreasing themotivationof students in subjects focusing on ICT, mathematics and/or chemistry. Furthermore, it is possible to say thatthere is nostatistically significant difference $(p=0.465695)$ in the frequency of men`s and women`s answers. Men and women both claim that teaching AutoCAD 2015 applications increased the students' motivation, and the results can therefore bedescribed asindependent ofgender.

The third question investigated was whether, from the teachers` point of view, the students had had serious difficulties mastering the subject matter. The teachers 'mission was to assess whether the difficulty of the subject matter corresponded with and was appropriate for the target group of students, and whether it would be possible to include the thematic unit in the teaching country-wide. A summary ofthe outcomes based on the teachers`answers isgiven inthe below Table number12.

Table12. Difficulty level of the subject matter focused on teaching AutoCAD 2015 applications

\begin{tabular}{|c|c|c|c|}
\hline \multicolumn{4}{|c|}{ Pearson`s chi square: $\mathrm{p}=0.46643$} \\
\hline \multicolumn{4}{|c|}{ Did the students have significant difficulties mastering the subject matter? } \\
\hline Gender of respondents & Men & Women & Row totals \\
\hline No, they did not - frequency & 10 & 6 & $16(84 \%)$ \\
\hline Yes, they did - frequency & 0 & 3 & $3(16 \%)$ \\
\hline All groups - frequency & 10 & 9 & $19(100 \%)$ \\
\hline
\end{tabular}

From the results shown in Table 12, it is quite clear that most teachers denied occurrence of any significant difficulties students might have had mastering the subject matter. They thus consider teaching AutoCAD 2015 applications appropriate for the target group of fourth and fifth year students of 8-year grammar schools. Furthermore, it is possible to say that there is no statistically significant difference $(p=0.46643)$ in the frequency of men`s and women`s answers. Men and women both claimed that the students had had no significant difficulties mastering the subject matter.

Another question examined was whetherthe teachers had noticed any interest from students in a higher amount of independent work based on model examples, supposed to be modified and completed by thelatter. Model examples were in the form of simple projects, meant to be further elaborated by newly created problem solv-ing teams, all by means of project training methods. A summary ofthe outcomesbased on the teachers`answers isgiven inthe below Table number13. 
Approaches to Supporting Technical Education at Humanities-Oriented Schools

Table13. Preference of independent work based on model examples

\begin{tabular}{|c|c|c|c|}
\hline Gender of respondents & Men & Women & Row totals \\
\hline No, they did not - frequency & 5 & 6 & $11(58 \%)$ \\
\hline Yes, they did - frequency & 5 & 3 & $8(42 \%)$ \\
\hline All groups - frequency & 10 & 9 & $19(100 \%)$ \\
\hline
\end{tabular}

From the resultsshown in Table 13, it is clear thatmost of the teachersobserved thatstudents had preferred rather frontal or group workwith model examples. Furthermore, it ispossible to say that there is nostatistically significant difference $(p=0.462529)$ in the frequency of men`s and women`s answers.

The fifth area of investigation focused on the question whether the teachers had spotted during teaching AutoCAD 2015 any preference by the students of frontal form of teaching to individual work, when solving the practical examples. The latter enabled the students to practice, practical drawings let them demonstrate particular theoretical partsof the curriculum. A summary ofthe outcomes based on the teachers` answers is given in the below Table number 14.

Table14. Preference of frontal teaching based on practical examples

Contingency table for: $\mathrm{n}=19$

Pearson`s chi square: $\mathrm{p}=0,875975$

Did the students prefer the frontal teaching part based on practical examples?

\begin{tabular}{|l|l|l|l|}
\hline Gender of respondents & Men & Women & Row totals \\
\hline No, they did not - frequency & 3 & 3 & $6(32 \%)$ \\
\hline Yes, they did - frequency & 7 & 6 & $13(68 \%)$ \\
\hline All groups - frequency & 10 & 9 & $19(100 \%)$ \\
\hline
\end{tabular}

From the results shown in Table 14 it is clear that a large majority of teachers did observe the students' interest in using practical examples in the form of frontal teaching. The teachers were thus able to demonstrate the particular applications of the acquired theory, which were later independently applied by the students in further assignments. Furthermore, it is again possible to conclude that there is no statistically significant difference ( $p=0.875975)$ in the frequency of men`s and women`s answers, as men and women both claim that students preferred mainly the frontal form of teaching.

Another question examined was whether the teachers had noticed any development of the students' knowledge due to the teaching of computer-aided drawing. In this case, however, not only knowledge related directly to teaching AutoCAD 2015 applications, but generally to ICT issues, was taken into account. The original assumption was that the teaching of these issues would parallel set up knowledge links to other topics. A summary of the outcomes based on the teachers` answers is given in the below Table number 15. 
Approaches to Supporting Technical Education at Humanities-Oriented Schools

Table15. Development of ICT knowledge due to the AutoCAD 2015 applications 'teaching

Contingency table for: $\mathrm{n}=19$

Pearson`s chi square: $\mathrm{p}=0,329722$

Does teaching of computer-aided drawing develop students”knowledge?

\begin{tabular}{|l|l|l|l|}
\hline Gender of respondents & Men & Women & Row totals \\
\hline No, it does not - frequency & 1 & 0 & $1(5 \%)$ \\
\hline Yes, it does - frequency & 9 & 9 & $18(95 \%)$ \\
\hline All groups - frequency & 10 & 9 & $19(100 \%)$ \\
\hline
\end{tabular}

From the results shown in Table 15it is clear thatall the teachers noticed that teaching AutoCAD 2015 had developed students' knowledgein other fieldsof I IT, too. Furthermore, it ispossible to conclude that these findings ( $p=0.329722$ ) are independent of thegenderof teachers, as the answers given by menand women correspond.

The seventh area examined was focused on the question whether the teachers had noticed any development of the students'skills due to the teaching of AutoCAD applications. As in the investigation area 6, in this case again not onlyknowledge related directly to teachingmath or chemistry, but generally to ICT issues, was taken into account. Once more, the original assumption was that teaching AutoCAD would parallel set up skill links to other topics. A summary ofthe results based on the teachers answers isgiven inthe below Table number16.

Table16. Development of ICT skills due to the AutoCAD 2015 applications `teaching

Contingency table for: $\mathrm{n}=19$

Pearson`s chi square: $\mathrm{p}=0,329722$

Does the computer-aided drawing teaching develop students`skills?

\begin{tabular}{|l|l|l|l|}
\hline Gender of respondents & Men & Women & Row totals \\
\hline No, it does not - frequency & 1 & 0 & $1(5 \%)$ \\
\hline Yes, it does - frequency & 9 & 9 & $18(95 \%)$ \\
\hline All groups - frequency & 10 & 9 & $19(100 \%)$ \\
\hline
\end{tabular}

From the resultsshown in Table 16 it is clear that all the teachers noticed that teaching AutoCAD 2015 had developed the students' skillsin other fields of I IT, too. Furthermore, it is possible to conclude that these findings ( $p=0.329722$ ) are independent of the gender of teachers, as the answers given by men and women correspond.

Another question examined was whether the teachers had observed at the students any development of positive attitudes and opinions to technology due to AutoCAD 2015 teaching. Once again, not merely the opinions and attitudes related directly to the teaching of drawing documentation, but in general the opinions and attitudes to technical facilities and technical education, were considered. A summary ofthe outcomesbased on the teachers`answers isgiven inthe below Table number17.

Table17. Development of positive opinions and attitudes on and to technology due to the AutoCAD 2015 applications' teaching

Contingency table for: $\mathrm{n}=19$

Pearson`s chi square: $\mathrm{p}=0,875975$

Does the computer-aided drawing teaching develop students`value orientation and/or their attitudes?

\begin{tabular}{|l|l|l|l}
\hline Gender of respondents & Men & Women & Row totals \\
\hline
\end{tabular}

American Research Journal of Humanities and Social Sciences 
Approaches to Supporting Technical Education at Humanities-Oriented Schools

\begin{tabular}{|l|l|l|l|}
\hline No, it does not - frequency & 3 & 3 & $6(32 \%)$ \\
\hline Yes, it does - frequency & 7 & 6 & $13(68 \%)$ \\
\hline All groups - frequency & 10 & 9 & $19(100 \%)$ \\
\hline
\end{tabular}

From the results shown in Table 17 it is clear thatall teachers did noticethat teaching AutoCAD 2015 applications developed students' attitudes and value orientation towards technology. Furthermore, it is possible to conclude that there is nostatistically significant difference $(p=0.875975)$ in the frequency of men`s and women`s answers, as menand women both claim that teaching AutoCAD 2015 applications develops attitudes and value orientation of students to technology.

The ninth investigated area focused on the question whether the teachers observed that teaching AutoCAD 2015 applications had developed students'c reativity and imagination. Creativity and imagination are essential partsof human personality, and therefore must be constantly stimulated and developed. A summary ofthe out-comesbased on the teachers'answers is given in the below Table number 18.

Table18. Development of creativity and imagination due to the AutoCAD 2015 applications' teaching

Contingency table for: $\mathrm{n}=19$

Pearson`s chi square: $p=0,278821$

Does the computer-aided drawing teaching develop students`creativity and imagination?

\begin{tabular}{|l|l|l|l|}
\hline Gender of respondents & Men & Women & Row totals \\
\hline No, it does not - frequency & 0 & 1 & $1(5 \%)$ \\
\hline Yes, it does - frequency & 10 & 8 & $18(95 \%)$ \\
\hline All groups - frequency & 10 & 9 & $19(100 \%)$ \\
\hline
\end{tabular}

From the results shown in Table 18 it is clear thatall the teachers observed development of the students' creativity and imagination due to the teaching of AutoCAD 2015. Furthermore, it is possible to con-clude that these findings ( $p=0.278821)$ are independent of the gender of teachers, as men and women agree on the claim.

The investigated question number 10 was whether the teachers observed at the students an ability to apply the outcomes of the teaching of AutoCAD 2015 applications outside the classroom, too. The teachers had an opportunity to respond to the question concerning the students'ability to independently create 2D and 3D drawing documentation also beyond the curriculum presented. A summary ofthe outcomesbased on the teachers'answers is given in the below Table number 19.

Table19. Ability to independently apply AutoCAD 2015 beyond training

\begin{tabular}{|c|c|c|c|}
\hline \multicolumn{4}{|l|}{ Contingency table for: $\mathrm{n}=19$} \\
\hline \multicolumn{4}{|l|}{ Pearson`s chi square: $p=0,905565$} \\
\hline \multicolumn{4}{|c|}{$\begin{array}{l}\text { Are students able to apply math and chemistry beyond training, that is to say subsequently to the computer- } \\
\text { aided drawing teaching? }\end{array}$} \\
\hline Gender of respondents & Men & Women & Row totals \\
\hline No, they are does not - frequency & 2 & 2 & $4(21 \%)$ \\
\hline Yes, they are - frequency & 8 & 7 & $15(79 \%)$ \\
\hline All groups - frequency & 10 & 9 & $19(100 \%)$ \\
\hline
\end{tabular}

American Research Journal of Humanities and Social Sciences

Page 15 
Approaches to Supporting Technical Education at Humanities-Oriented Schools

From the resultsshown in Table 19 it is more than clear thatmost of the teachers observed that teaching AutoCAD 2015 enabled the students to create 2D and 3D drawing documentation outside the classroom, too. Furthermore, it ispossible to conclude that these findings ( $p=0.905565)$ are independent of the gender of teachers, as men and women agree on the outcome.

Another area examined was focused on the question whether the teachers had observed at the students better understanding of the operating principles of computer technology as a result of being taught AutoCAD 2015 applications. The teachers were asked to answer the question of whether the teaching of creating 2D and 3D drawings haddevelopedcross-curricular links,and therefore was a suitable complement to teaching other subjects as well. A summary ofthe outcomes based on the teachers'answers is given in the below Table number 20.

Table20. Rate of development of understanding the ICT operating principles

\begin{tabular}{|c|c|c|c|}
\hline \multicolumn{4}{|c|}{$\begin{array}{l}\text { Contingency table for: } \mathrm{n}=19 \\
\text { Pearson`s chi square: } \mathrm{p}=0,514585 \\
\text { Do students understand the ICT operating principles better now? }\end{array}$} \\
\hline Gender of respondents & Men & Women & Row totals \\
\hline No, they do not - frequency & 3 & 4 & $7(37 \%)$ \\
\hline Yes, they do - frequency & 7 & 5 & $12(63 \%)$ \\
\hline All groups - frequency & 10 & 9 & $19(100 \%)$ \\
\hline
\end{tabular}

From the results shown in Table 20 it is quite clear that most of the teachers observed that the students understand the operating principles of computer technology better now. Furthermore, it is possible to conclude that these findings ( $p=0.514585$ ) are independent of the gender of teachers, as men and women agree on the outcome.

The last question to investigate was whether the teachers had observed any increase in the students` interest in the issue of computer-aided drawing due to the teaching of creation of 2D and 3D drawing documentation. Teachers were asked to answer the question focusing on whether teaching AutoCAD 2015 applications had developed the students ' interest in using computer technology not only for entertainment and communication, but also for the creation of real projects. A summary of the outcomes based on the teachers answers is given in the below Table number 21 .

Table21. The level of interest in AutoCAD 2015 applications

\begin{tabular}{|c|c|c|c|}
\hline $\begin{array}{l}\text { Contingency table for: } \mathrm{n}= \\
\text { Pearson`s chi square: } \mathrm{p}= \\
\text { Did the students`interest }\end{array}$ & er-aid & & \\
\hline Gender of respondents & Men & Women & Total rows \\
\hline No, it did not - frequency & 0 & 2 & $2(11 \%)$ \\
\hline Yes, it did - frequency & 10 & 7 & $17(89 \%)$ \\
\hline All groups - frequency & 10 & 9 & $19(100 \%)$ \\
\hline
\end{tabular}

From the results shown in Table 21 it is clear that the teachers did observea significant and large increase in the students' interest in AutoCAD 2015 applications and we can thus claim that the students do not prefer to continue using the acquired knowledge for communication and entertainment only, but rather for real projects or applications. Furthermore, it is possible to conclude that these findings $(p=0.115037)$ are independent of the gender of teachers, as men and women both claim the same. 


\section{DISCUSSION}

The idea of natural ICT usage, which means modern didactic tools, among nowadays students is a fact supported by two main arguments. The first one draws from the fact that nowadays children use and handle modern IT with absolute certainty and self-confidence.The second reason comes from the ICT usage statistics based on age showing that unlike the older generations, almost all children use the Int ernet and computer (Lupač, 2011). American author Don Tapscott (1998) based his theory on these two arguments in 1998 claiming that the powerful family model is corrupt because it is the children who educate their parents how to live in the digital environment. His label N/GEN and digital generation was soon supported by others: digital natives (Prensky, 2001), homo-zappiens(Veen \& Vrakking, 2006), digitally born (Palfrey \& Glasser, 2008) and others. "Digital natives are used to getting information very quickly. They like doing more activities at the same time (multitasking). They prefer working with the picture material before text. They also prefer random attitude towards information (hypertext) and they like working in the net environment (online) best. They expect immediate praise and frequent appreciation of their own work (Prensky, 2001). Prensky's and Tapscott's ideas have become very influential and several researchers have tried to support or disprove their thoughts with variable success (Bennett, Maton \& Kervin, 2008).

Although the author of the presented study does neither support nor disprove the idea of different approach to "digital natives" education, he thinks that through monitoring the educational reality and the opinions of the people involved, an appropriate space for developing professional discussion of this phenomenon can be created. That is why the discussion should cover not only the issue of actual use of ICT in teaching, but also the problems of creating meaningful educational content,which is further developed by these technologies. Increasingly, we are witnesses to the integration of information and communication technology in the form of touch devices, smartphones, and so on, to the process of teaching. However, the integration is often rather calculated, and sometimes provoked by commercial companies, which results in many difficulties, both in terms of pupil and teacher.The integration, sometimes also referred to as the diffusion of innovations in education (Rogers, 1995), is conditioned by the presumption of the existence of the generation of "digital natives".

The deployment of ICT in education must thus take into account not only the needs and interests of the pupils, but also their further development, not only in the narrow field of information technology, but also in other equally important fields such as mathematics, chemistry or technical sciences. It is exactly the area of polytechnic education which is often overlooked and replaced by IT education. However, as shown by the above experimental educational content, it is possible to link the two areas more. Moreover, as our research showed, an integrated, interdisciplinary-based learning content attracted not only students, but was appreciated by the teachers as well.

In such a rapidly developing field like this one we cannot keep our distance necessary for "evaluating carefully and impartially", which is necessary for supported professional discussion. As a result, we perceive the above mentioned facts as an impulse to develop further discussion, and as a stimulus to a responsible and balanced attitude towards the needs of pupils and students, whose training shall be enhanced by a meaningful, interdisciplinary use of information and communication technology.

\section{CONCLUSIONS}

The above described experimental educational content focused on an enrichment of the teaching of mathematics and chemistry with a practical application of the computer-aided technical drawing, represents an innovative way of using modern information and communication technologies in education. As it is obvious from the above described research, the experiment and its impacts positively influenced the formation of key educational activities for students in upper secondary education, and at the same time increased the qualifications of teachers of 6 and 8 year grammar schools, where the experimental education was implemented. 
The benefits and added value for the teachers was gaining new skills, expansion of professional skills, a significant improvement in the conditions for the preparation and implementation of the teaching of technically oriented graphics systems and, last but not least, a free access to the relevant electronic educational materials.

With respect to students, the experimental educational content offered them an opportunity to learn about and improve in the field of creating 2D and 3D drawings in AutoCAD 2015 system. They were enabled to develop individual skills in a new way, to solve tasks in a more attractive way and independently, based on the acquired knowledge of work with ICT, to use all means of communication effectively and creatively, and, last but not least, to accept responsibility for their own work. As a whole, all these skills can significantly contribute to the wider adaptability of students in further studies at universities.

\section{REFERENCES}

Babbie, E. R. 2014. The Basics of Social Research - 7th Edition. Belmont, CA: Wadsworth Publishing.

Bennett, S., Maton, K., \& Kervin, L. 2008. The 'digital natives' debate: Acritical review of the evidence. British Journal of Educational Technology 39(5), 42-52.

Bracey, P. 1994. Cross-curricular and cross-subject links - middle management perceptions. Educational Review, 46, 219-231. doi: 10.1080/0013191940460301

Ferreira, M. E., Caires, C., \& Pitarma, R. 2015. Health and sustainable behaviours: a pedagogical and didactic experiment in preschool teaching. International Journal of Knowledge and Learning, 3, 238-257. doi: 10.1504/ IJKL.2015.073462

Gardner, H. 1999. Intelligence Reframed: Multiple Intelligences for the 21st Century. New York, NY: Basic Books.

Granath, J. 2003. Design theoretical approach to learning in technology - a way to enhance interest in future professional studies, Teoretyczneipraktyczneproblemyedukacitechnicznejiinformatycznej, Rzeszów, WydawnictwoOświatowe: Fosze. pp. 128-139.

Idrus, H., Mond, D. H., \& Abdullah, N. 2010. Integrating critical thinking and problem solving skills in the teaching of technical courses: The narrative of a Malaysian private university. Engineering Education, 5(2), 258-263.

Jirotková, D. 1990. Development of spatial imagination of pupils. Komenský, 5(1), 48-62.

Klement, M. 2003. Graphics and multimedia - AutoCAD 2000. Olomouc: Publishing UP Olomouc.

Klement, M., \& Kubrický, J. 2014. Possibilities of Learning AutoCAD 2015 for Grammar Schools, Trends in Education: Information Technologies and Technical Education (202-209.)Olomouc, Gevak.

Klímek, P. \& Kasal, R. 2009. Iomputer processing of data in NTITI NTI II. Bučovice: Martin Stř́íz.

Kropáč, J. 2004. The issue of a comprehensive approach to teaching technical subjects. e-Pedagogium, 4(1), 32-48.

Lee, H., Rojewski, J. W., \& Gregg, N. 2016. CausalEffectsof Career-TechnicalEducationon Postsecondary Work Outcomes of Individuals with High-Incidence Disabilities. Exceptionality, 24(2), 79-92.

Leung, K., \& Wang, J. 2015. Social processes and team creativity in multicultural teams: A socio-technical Framework. Journal of Organizational Behavior, 7, 1008-1025. doi: 10.1002/job.2021

Lupač, P. 2011. Myths (and reality) Digital Generation. Lupa.cz, 6(1), 1-4. 
Approaches to Supporting Technical Education at Humanities-Oriented Schools

Manullang, B., \& Kons, S. M. 2012. The integration of soft skill and hard skill in learning revolution. In Education Technology and Computer. Shanghai, 3(1), 436-439.

Markson, L., \& Paterson, K. B. 2009. Effects of gaze-aversion on visual-spatial imagination. British Journal of Psychology, 100, 553-563. doi: 10.1348/000712608X371762

Palfrey, J., \& Glasser, U. 2008. Born Digital: Understanding the First Generation of Digital Natives. New York, NY: Basic Books.

Prensky, M. 2001. Digital Natives, Digital Immigrants: Do They Really Think Differently? On the Horizon 9(5), 7-11.

Reis, N. T., \& Garcia, N. M. 2016. Space education in the elementary school: A working proposal using the action and reaction principle. Revista Brasileira de Ensino de Fisica, 28(3), 361-371.

Rogers, E. M. 1995. Diffusion of innovations. New York, NY: The Free Press.

Silva, M. R., Pelissari, L. B., \& Steimbach, A. 2013. Youth, school and work: attendance and dropout in technical professional secondary education. Educação e Pesquisa, 39, 224-247. doi: 10.1590/S151797022012005000022

Tapscott, D. 1998. Growing Up Digital: The Rise of the Net Generation. New York, NY: McGraw-Hill.

Veen, W., \&Vrakking, B. 2006.Homo Zappiens. Growing Up In A Digital Age. New York, NY: Network Continnum Education.

Citation: Milan KLEMENT, "Approaches to Supporting Technical Education at Humanities-Oriented Schools." American Research Journal of Humanities and Social Sciences, vol 3, no. 1, 2017, pp. 1-10.

Copyright (C) 2017 Milan KLEMENT, This is an open access article distributed under the Creative Commons Attribution License, which permits unrestricted use, distribution, and reproduction in any medium, provided the original work is properly cited. 